\title{
Pension Changes in China and Opportunities for Insurance
}

\author{
Qixiang Sun $^{\mathrm{a}}$ and Lingyan Suo ${ }^{\mathrm{b}}$ \\ ${ }^{a}$ School of Economics, Peking University, Haidan District, Beijing 100871, P.R. China. \\ E-mail: qusun@pku.edu.cn \\ ${ }^{\mathrm{b}}$ School of Public Health, Boston University, 715 Albany Street, 580-3, Boston, MA 02118, U.S.A. \\ E-mail: lingyan@bu.edu
}

In face of the large ageing population and increasing dependence ratio, China is aiming to find an efficient, stable, and sustainable pension system. This article briefly examines the changes that have occurred in China's pension system and explores the pros and cons of the current system. Although China has made a good start in laying the foundation for a multipillar pension system, pension reform is still incomplete and many important issues remain. Since the social insurance system alone cannot realistically accomplish the task of old-age security, the private sector, including the insurance industry, should be mobilized to play an active role in China's pension system.

The Geneva Papers (2007) 32, 516-531. doi:10.1057/palgrave.gpp. 2510150

Keywords: pension system; pension reforms; old-age social insurance; ageing; China

\section{Introduction}

While global ageing represents a triumph of medical, social, and economic advances, it also presents tremendous challenges. Longevity deeply and enduringly affects disease patterns and prevalence, labor supply, trade, migration, size and shape of government budget, and so on. The trend of ageing poses severe challenges to pension planning for a society in which lifetime jobs are no longer the norm. In order to provide the elderly with a decent standard of living without imposing a crushing burden on the young, an increasing number of countries have long been evaluating the sustainability of their old-age social insurance systems and considering some sort of reform. China, as a developing country with the world's largest population, is one of these.

As in many parts of the world, people in China are now living longer. We are seeing a significant age shift towards the older end of the age spectrum, driven by rising life expectancy, falling fertility rates, the family planning policy, and changes in people's values. According to the 1st National Population Census in 1953, just about 4 percent of China's population was over 65 in the early 1950s. This ratio has increased to over 9 percent as of the year 2005. ${ }^{1}$ By 2035, about 20 percent of the population will be 65 and over, an increase of some 200 percent from the current level in the number of seniors, while there will only be a negligible increase in the number of 20 to 64-yearolds (about 6 percent). As described in Figure 1, the ageing trend is characterized by an

${ }^{1}$ National Bureau of Statistics of China (2006). 

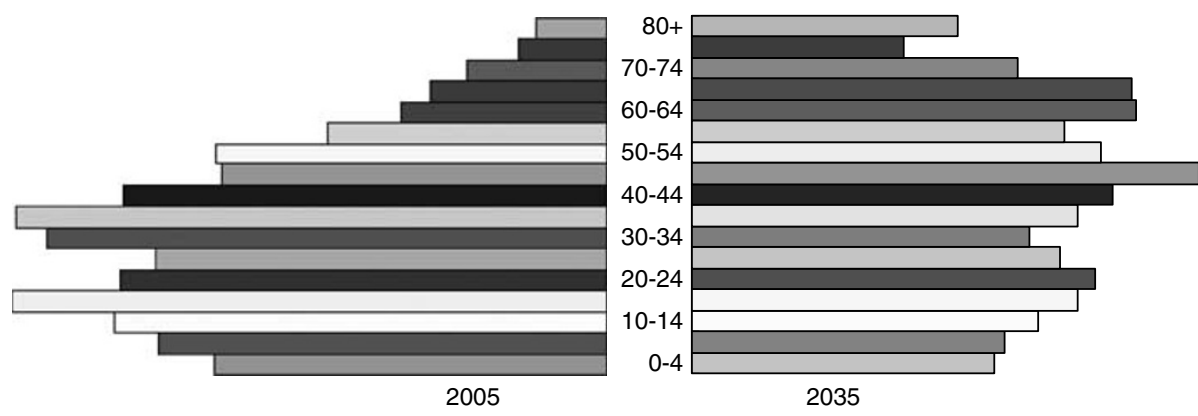

Figure 1. Population pyramids of China in 2005 and 2035.

Source: U.S. Census Bureau, International Database.

upward shift in the age profile (the median age will increase to 43.3 in 2035 from 32.3 in 2005) and by pensioners who are getting older. People aged 80 and over are a fastgrowing cohort and numbers will nearly quadruple by 2035 to approximately 62 million, over 4 percent of China's population. Meanwhile, the average family size has been shrinking. The 4th National Population Census shows that one family has 3.44 persons on average, as compared to 4.33 in $1953 .^{2}$ Instead of large families consisting of several generations and many members, small families have now become the norm in China, which means the traditional informal family support for old-age security is losing its reliability and credibility.

In the face of the large population and the evolving demographic mix, China is aiming to find an efficient, stable, and sustainable pension system. Old-age security is one of the first components of the social security system in China to be selected for reform as a key aspect of China's market-oriented reform and an important theme of the construction of a "Harmonious Society," which is at present the dominant socioeconomic ideology serving as the guiding direction of the Communist Party of China. This article will briefly examine the changes that have occurred in China's pension system, explore the pros and cons of the current multi-pillar system, and discuss the potential for the insurance industry to play a role in the old-age security system.

\section{Pension reform in China}

China established its dualistic structure of social and economic development just after the People's Republic of China was founded, which led to the long-term coexistence of two differentiated sectors, urban and rural, within the same society and strict control of labor migration between these two sectors. In view of the entitled rights to land of rural residents, the central government considered urban residents as proletarians who possessed neither capital nor the means of production, and thus required them to earn 
a living through the sale of their labor endowments. Efforts to establish a formal social security system were then concentrated on urban areas. The pension system in China naturally followed this pattern. Our examination of the reforms in China's pension system will build on this dualistic basis.

\section{Changes in the urban pension system}

China's efforts to establish the social insurance system (previously called the labor insurance system), which targeted urban residents and began shortly after the People's Republic of China was founded, were held back during the Cultural Revolution. The Ministry of Finance promulgated The Opinions on the Reform of Several State-Owned Enterprises' Financial Systems (draft) in February 1969, which required that stateowned enterprises (SOEs) stop collecting social insurance funds, and instead treat reimbursements for payments of labor insurance as a non-operating expense, that is, to pay pension and other work-related benefits solely out of each enterprise's current operating funds. The labor insurance evolved into a defined benefit pay-as-you-go (PAYG) system, pooling risk within a single enterprise and thus laying the foundation of China's urban pension system. ${ }^{3}$

This old system, especially the pension part, later proved to be a huge obstacle to the reform of China's economic system. The generous pension eligibility criteria, which granted lifetime pensions upon retirement at age 50 to female workers, at age 55 to female cadres, and at age 60 to male workers with employment records of over 20 years, combined with the ageing trend, led to a continuous increase of pension benefits with an annual growth rate of over 20 percent from 1980 to 1992. As a consequence, the financial stability of this PAYG system was in question. The competitiveness of enterprises with more retirees, most of which were SOEs, relative to those with younger workforces, most of which were newly established private rivals, was severely threatened by the rising financial burden. Things got worse as the reform progressed, since SOEs lost their privilege to pass along deficits to the government and had to be financially independent while the number of SOEs allowed to declare bankruptcy was controlled. In the meantime, the increase in the number of uninsured became a big issue. Urban employment in the private sector, where old-age security benefits were usually small or nonexistent and deregulated, began to grow rapidly in the 1980s, increasing from almost zero in 1978 to over 18 percent in the early 1990s. ${ }^{4}$ A pension system focused on single enterprises and the big difference in coverage between the public and private sectors then led to compromised labor mobility.

As the pressures mounted, the 3rd Plenary Session of the 14th Communist Party of China's (CPC) Central Committee held in 1993 issued The Decisions on Several Issues about the Establishment of a Socialist Market Economic System. They sought to establish a multi-pillar social security system characterized by a combination of

\footnotetext{
${ }^{3}$ Before the market-oriented reform, the dominant public ownership had two kinds of presence: One of them is state ownership and collective ownership. Urban collective enterprises usually offered pension benefits patterned after the state system.

${ }^{4}$ National Bureau of Statistics of China (2006).
} 
mandatory social pooling and individual accounts with supplemental voluntary enterprise-sponsored pensions and individual savings, indicating the consensus had been achieved that the old-age security responsibilities should be shared among the government, employers, and individuals. It was stated that the system would be designed to suit China's economic development, that is, the state pension system would only focus on providing the most basic economic security to retirees and coverage was to be extended to all urban workers, including those outside the state and collective sectors. The Decisions also established the basic principle that the old-age security system would still be built on the basis of urban-rural separation and that the formal efforts of institutional development would be mostly concentrated in the urban pension system. Following the guidelines, regional and industry-wide ${ }^{5}$ experimental efforts were conducted with respect to their different situations. But the variety in the financing and definition of benefits among different risk pools turned out not to be good for labor mobility and financial stability.

In July 1997, the State Council issued The Decision on Establishing a Unified Basic Old-Age Insurance System for Employees, requiring all work units falling under the jurisdiction of an administrative pool to contribute a uniform percentage of their total wage bill to the pool, and for pensions to all retired workers within that pool then to be paid from the pooled pension fund. Tax incentives were also provided to encourage establishment of supplemental pension plans by enterprises. Then The Notice to Establish Provincial Pools of Basic Old-Age Insurance followed suit in August 1998, expanding pension pools from the county, city, or industry level to the higher provincial level. An important argument for moving pools to the highest level possible is to facilitate the development of labor markets. In the same year, the Ministry of Labor and Social Security (MOLSS) was established and took the responsibility for drafting old-age insurance policies, organizing the implementation, supervision, and inspection of these policies, formulating policies concerning the collection, payment, management, and operation of old-age insurance funds, implementing administrative supervision of the management of funds, and drafting policies concerning the supplementary old-age insurance.

The general framework of the current urban pension system was then defined, but the reformed urban pension system is still evolving. A complete set of national laws and regulations are in the process of being promulgated, among which the newest are The Decision of the State Council on Further Improvement of Basic Old-Age Insurance System (2005) and The Trial Measures of Employer Pension (2004). Although the social old-age insurance reform lagged behind real economic reforms, China's leaders are now reminded almost daily that social security reform is a top priority. Details of the current urban pension system will be discussed in the next section.

\footnotetext{
${ }^{5}$ By the end of 1993, 11 industries had established their own risk pools, including the railway, highway transportation, post service, water conservancy, airline, coal, non-ferrous metals, electricity, gas and oil, banking, and construction industry, which were then monopolized by the state and directly controlled by the central government.
} 


\section{Evolution of the rural pension system}

For rural residents in China, revenues from land and family support have long been taken as the backbone of old-age security, and the rural pension system is still quite undeveloped in view of the reality that about 60 percent of the population lives in rural areas. By focusing only on the urban labor force, the reformed old-age security system is unlikely to address the issue of growing rural-urban inequality very well.

A tentative, voluntary, defined contribution old-age insurance program in rural areas, which tried to establish social risk pools at the county level, was launched by the Ministry of Civil Affairs in the early 1990s. ${ }^{6}$ This plan put the primary financing responsibilities on individuals and encouraged local government to support it with a subsidy. It turned out that only in the economically better-off areas would local governments and/or rural township enterprises offer to match a portion of the individual's contribution. This plan could apparently only appeal to a limited number of rural households. It is not attractive to residents in wealthy rural areas, as they can invest their money in other instruments that are perceived to be more profitable and secure; for households in poor areas participation is not economically feasible. In fact, only 53.7 million rural residents were enrolled in some kind of rural old-age insurance plans at the end of 2006 and 3.6 million received $\mathrm{RMB}^{7} 3$ billion in old-age benefits during that year. ${ }^{8}$

In view of these facts, the State Council presented a White Paper outlining programs for senior citizens, which urges increasing efforts to explore possible solutions for the rural old-age security system as of December 2006. According to the blueprint of the Whiter Paper, the formalized old-age insurance system is still in the experimental stage and seniors' entitled rights to the management of contracted land are still regarded as the key component of the rural old-age security system as their obligated providers are expected to farm the land and care for them with the proceeds. ${ }^{9}$ The government encourages people to sign a "family support agreement," which stipulates how the elderly person is to be provided for and what level of livelihood he/she will have. Villager committees or other relevant organizations are to supervise the implementation of the contract. By the end of 2005, some 13 million "family support agreements" had been signed. ${ }^{10}$

\footnotetext{
${ }^{6}$ The Ministry of Labor and Social Security took over the rural old-age pension programs after its establishment.

${ }^{7}$ RMB stands for Chinese currency, of which the full name is Ren Min Bi. In 2005, the average exchange rate of RMB against the U.S. dollar was 8.19 yuan per U.S. dollar. See National Bureau of Statistics of China (2006).

${ }^{8}$ Ministry of Labor and Social Security (2007).

${ }^{9}$ Financial aid will be offered by the government to disabled and old rural residents without family support.

${ }^{10}$ See News Office of the State Council (2006).
} 


\section{The current urban pension system}

\section{Urban basic old-age insurance}

The current basic social pillar of China's urban pension system seeks a balance between incentives for participation and social equity as indicated by its benefit formula. The benefits of urban basic old-age insurance have two components. The social pool finances the first part, the so-called "primary pension," with contributions from employers' pre-tax income, which equals a portion of a pensioner's wage (the contribution rates of different regions vary by around 20 percent). ${ }^{11}$ Eligible retirees, whose duration of contributions exceeds the minimum of 15 years, can get a monthly primary pension equal to a percentage of the local average social wage prevailing in the year prior to the retirement and indexed for inflation, providing for a transfer from higher paid workers to lower income workers. In order to reward longer enrollment, the percentage received as primary pension is now linked to the years of qualified service in a so-called "one year, one per cent" way, that is, retirees whose employers have contributed to the pension fund on their behalf for $x$ years will be paid $x$ percent of the reference wage, which is the local average social wage prior to one's retirement, as primary pension.

The second part is funded by the individual account savings with contributions, generally, coming from the employee's pre-tax income (equal to about 8 percent of one's wage), and retirees can get a monthly "individual account pension" based on the balance of one's own individual account before retirement and a rough estimation of the residual life expectancy of the retiree. For example, in many risk pools, a person who retires at age 50 can get a monthly payment equal to $1 / 195$ of the balance while another who retires at age 60 can get $1 / 139$ of the balance as the monthly individual account pension benefit. ${ }^{12}$ Since this non-forfeiture defined contribution plan is fully funded, the pensioners are expected to have a stake in the continuation and accumulation of the account. These two components are expected to attain an income replacement ratio of 58.5 percent for retirees.

Many pools have set limits on the salary or wage subject to the pension contribution rate for both employees and employers. Most of them specify that the portion of a wage over 300 percent of the local average wage is exempted from the contribution levy. On the other hand, regardless of how low the actual wage is, both the employer and employee are required to pay the pension levy based on a minimum wage level, usually defined as 60 percent of the local average wage. This regulation is intended to add a measure of equality into the basic social pillar and may discourage employers from paying low wages to reduce their pension liabilities.

\footnotetext{
${ }^{11}$ For individual-owned business employees and the self-employed, contributions are based on the local average wage for the previous year. This avoids the high administrative costs associated with determining and verifying wage rates for these individuals.

${ }^{12}$ Before the issuance of The Decision of the State Council on Further Improvement of Basic Old-Age Insurance System for Employees in 2005, almost all the risk pools paid qualified retirees a fixed percentage of reference wage (20 percent in most cases) as the primary pension benefit, thus providing little incentives to extend the duration of contributions. What's more, they paid $1 / 120$ of the balance of one's individual account as the monthly individual account pension benefit, i.e. assuming an average residual life expectancy of retirees of 10 years. This kind of assumption is obviously unrealistic. Risk pools are now changing to the new benefit formula.
} 
With regard to the issue of financial stability, the government is to contribute to this issue as needed in its role as pension guarantor. If one old-age insurance pool cannot meet its full obligations, the government will provide direct subsidies and might allow the pool to adjust the contribution rate. During 2006, government subsidies to the urban basic old-age insurance fund totaled RMB 97 billion yuan, including the central government budget of RMB 77 billion yuan. ${ }^{13}$ Furthermore, the central government decided to establish the National Social Security Fund (NSSF) in 2000 as strategic reserves to meet the challenges when the ageing population reaches a peak. NSSF is supervised by a specific government agency, the National Council for Social Security Fund (NCSSF), and is funded by capital and equity assets derived from reductions of state-owned shares, fiscal allocation of the central government, capital raised in other ways with approval of the State Council and investment proceeds. By the end of 2005, NSSF had built up its equity to RMB 195 billion yuan. ${ }^{14}$

\section{Employer pension plans}

The second pillar of China's current targeted pension system is composed of voluntary enterprise-sponsored pension plans, which were labeled "supplemental old-age insurance" before the issuance of The Notice to Implement the Tentative Protocol of Improvement of Urban Social Security System by the State Council in 2000. As prescribed by The Notice and The Trial Measures of Employer Pension (2004), enterprises can establish fully funded pension plans for employees with contribution from both employers and employees if they meet the full obligations of urban basic old-age insurance. Incentives provided as contributions within 4 percent of the total payroll by the employer in experimental regions designated by the State Council can be deducted from the enterprise's taxable income. ${ }^{15}$

A qualified employer pension plan should be reviewed and recognized by the local agency of MOLSS ${ }^{16}$ and follow current regulations. Specifically, employers and employees must entrust the pension funds to a special-purpose employer pension council established within the enterprise or other qualified legal entity, and the fiduciary will then appoint the trustee, record keeper, and investment custodian for the trustor's best interests. Qualification, accredited by MOLSS, is a prerequisite for any financial institution to be involved in employer pension fund management according to the Interim Measures for the Qualification Accreditation of Enterprise Annuity Fund Management Institutions, which took effect in 2005, and poses new challenges to the coordination of different regulators' efforts. ${ }^{17}$

${ }^{13}$ Ministry of Labor and Social Security (2007).

${ }^{14}$ National Council for Social Security Fund (2006).

${ }^{15}$ This percentage may be higher in some other jurisdictions, for example 5 percent in Shanghai.

${ }^{16}$ State-owned enterprises financially subject to the Ministry of Finance should directly file their pension plans to the Ministry of Labor and Social Security.

${ }^{17}$ At present, the financial institutions regulation system in China is built on a separated basis. Insurance companies are regulated by the China Insurance Regulatory Commission (CIRC), while China Banking Regulatory Commission (CBRC) supervises banking institutions and trust facilities, and the China Securities Regulatory Commission (CSRC) is authorized to regulate the securities market. 
Both the employer and employees should contribute to the pension plan and funds accumulate in the employee's individual accounts. As a matter of fact, there were already various kinds of employer-funded pension plans in existence before the issuance of The Trial Measures of Employer Pension, such as those administered by the social insurance agencies, group annuity insurance operated by insurance companies, etc. The second pillar is still in transition and must still be adapted to the legal framework. By the end of 2006, about 24,000 enterprises had established their employer pension plan and thus provided supplemental old-age coverage for 9.6 million employees. $^{18}$

Since the establishment of employer pension plans is voluntary and depends on the willingness and financial strength of the employer, it is not surprising to see the quick development of the second pillar at first in some monopoly industries, such as electricity, gas and oil, and telecommunication. For example, the principal and interest of the electricity industry's employer pension plans alone amounted to about 13 percent of the national balance. Employees in numerous, mostly small and sometimes informal, private companies are still rarely covered by employer pension plans.

\section{Individual retirement arrangements}

As a country with a history of more than 5,000 years, China has a rich culture and a wealth of traditions which play an important role in shaping people's behavior. The long-pursued traditional value of "storing grain in abundant years for famine and raising children when young for support in old age" made personal savings and family support the most important personal old-age security arrangement, and made the development of commercial pension insurance in China difficult. The Western powers introduced a formal insurance system into China around the end of the Qing Dynasty (1644-1911), China's last feudal dynasty, but the development of the life insurance industry was not significant at all until China confirmed its determination to give up its centralized planning economy system and open up to the world to build a marketoriented economy around the early 1990s. ${ }^{19}$

Since the "from the cradle to the grave" economic security is no longer possible, individuals need to establish some formal personal retirement arrangements by themselves in this ageing era. It is not hard for a nation with a high propensity to save to adapt to these new circumstances. Figure 2 shows an increasing trend of national saving rate since the initial stage of China's economic system reform in the early 1980s. People began considering commercial pension insurance as an option to prepare for post-retirement living needs. At the end of June 2006, about 31 million people were covered by some kind of personal pension insurance and China's insurance companies were offering 386 kinds of individual pension policies to the public. $^{20}$

\footnotetext{
${ }^{18}$ Ministry of Labor and Social Security (2007).

${ }^{19}$ See Sun et al. (2007).

${ }^{20}$ CIRC.
} 


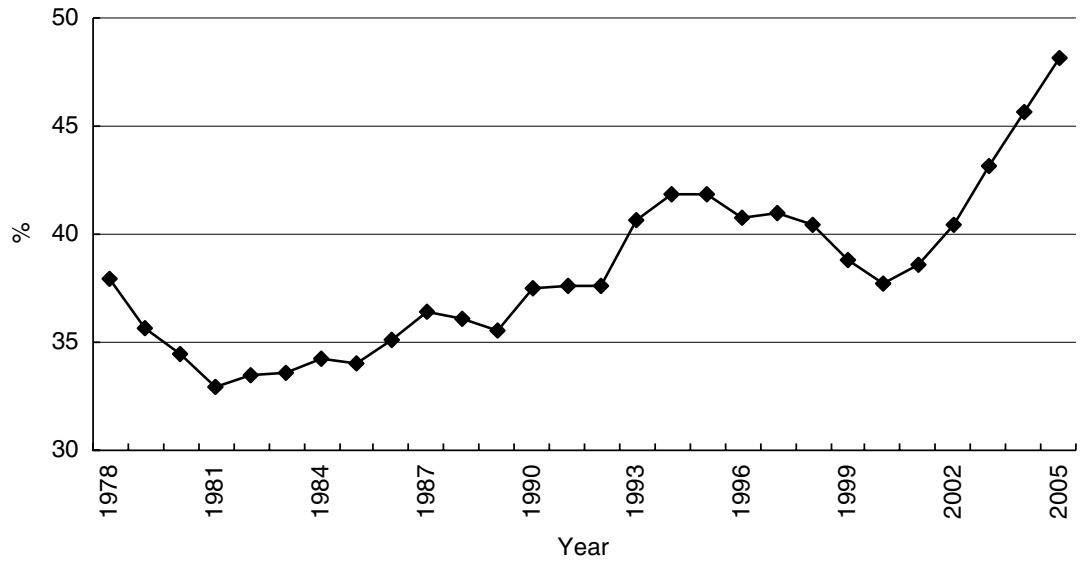

Figure 2. China's national savings rate: 1978-2005.

Source: National Bureau of Statistics of China (2006), China Statistical Yearbook 2006, Beijing: China Statistics Press and Beijing Info Press.

\section{An evaluation of the current social pillar of the pension system}

Although the pension system in China is still in the process of being reformed and refined, it is not too early to assess how well it has dealt with the weaknesses of the former system. The suitability of the new system for an ageing society and its implications for future development are also of interest.

\section{Expansion of coverage and the urban-rural divide}

Under the reforms, top priority was given to unifying and standardizing the pension system for SOEs, which were the major areas in need of change, especially in the initial stages. Generally speaking, the social pillar of old-age welfare now covers almost all the employees of SOEs. The government has also tried hard to expand coverage to other types of urban enterprises (collective and private) and other types of employees (such as temporary or contract workers and the self-employed) during this process. Owing to the continuous efforts to expand pension coverage and to refine the social pillar, about 187.7 million people were covered by urban basic old-age insurance, including 46.4 million beneficiaries at the end of 2006, which means that 49.9 percent of people currently employed in urban areas were enrolled into the social pillar of China's pension system, compared to 41.7 percent a decade ago. ${ }^{21}$ Although China has made notable progress in the expansion of coverage, it is true that many workers outside the state sectors have to rely on personal savings and their families to support themselves in old age; so do their dependents as the employment-based coverage does not extend to them automatically.

\footnotetext{
${ }^{21}$ Ministry of Labor and Social Security (2007).
} 
To make things worse, expansion of basic urban old-age insurance coverage mainly relies on the government's executive authority. Proper legal enforcement and sanction measures are lacking. At present, supervision by the agencies of the MOLSS is the most important safeguard of workers' rights and benefits. However, since the labor supervision system had only 3,201 agencies and a staff of $22,000^{22}$ in 2006, its oversight and enforcement role is less than satisfactory. Many enterprises, especially those in labor-intensive industries, can still sign employees to multiple short-term contracts and simply deny their pension benefits while standing a good chance of escaping the punishment. The abundant labor force encourages this behavior. Rural-urban labor mobility has increased tremendously with the easing of restrictions on labor movements in the early 1980s. Tens of millions of rural laborers migrate annually to urban areas to work; some of them work only part of the year in the city, while others have lived and worked in the city for several years but are seldom allowed to establish permanent urban residency. These people are most likely to be and are in fact often denied pension coverage and other work-related benefits. It is understandable that further expansion of coverage is not easy.

While the reformed pension insurance system is embracing more urban workers, pension coverage is still not accessible for a vast majority of the rural labor force, which presently comprises about 63 percent of China's total labor force with a number of 480 million. The family support-based old-age security system is apparently vulnerable and problematic in an era characterized by ageing and urbanization and calls for further reform. In 2005, about 57 percent of the population lived in rural areas while the GDP from agriculture, forestry, animal husbandry, and fisheries amounted to only 12.6 percent of the national total. ${ }^{23}$

In a word, China's present half-reformed system is plagued by incomplete coverage and uneven access to benefits. Poor elderly people are less likely to be covered. Even for those with incomes above the societal average, coverage provided by the first pillar is inadequate. According to a survey conducted by the Principal Life Insurance Company in 2003 of 500 employees with annual incomes exceeding USD 2,800, only 23 percent of the interviewees believed that the government would help them with a decent life in old age and 49 percent thought they would need family support as an important supplement. ${ }^{24}$ Long-term efforts are still needed to further expand the coverage of the social pillar of China's pension system in order to expand social support to the vulnerable population.

\section{Financial sustainability and "empty" individual accounts}

The transformation of China's urban old-age insurance system from a PAYG system to a partially funded one brings up the problem of implicit pension debt (IPD). Under the former PAYG system, contributions from the working generation were directly transferred to the retirees and there were no accumulated funds. After the

\footnotetext{
22 Ibid.

${ }^{23}$ National Bureau of Statistics of China (2006).

${ }^{24}$ Principal Life Insurance Company (2004).
} 
establishment of the partially funded pension system, contributions to the PAYG part were not enough to pay for the pension benefits of those who had retired before the "new deal" as well as to fund the pension plans of the current workforce. ${ }^{25}$ The new urban social old-age insurance system was born to be congenitally deficient in financial sustainability. At the same time, many enterprises per se were in financial difficulties and could not make the contributions as they should. Besides, as a part of SOE reforms in the 1990s, millions of SOE employees accepted early retirement benefits so that SOEs could shed redundant labor to improve their competitiveness. This policy made the generous eligibility criteria of social old-age insurance even more liberal. Not only was the number of retirees significantly increased, but also the average retirement period was expanded. All these factors, compounded by the inevitable trend of ageing, resulted in a huge volume of IPD.

In order to meet its current obligations, the Chinese government not only granted fiscal subsidies to the system but also chose to utilize the funds which should have been deposited into individual accounts, and in turn gave birth to "empty individual accounts," or, in other words, notional defined contribution (NDC) accounts. The rapidly enlarging IPD resulting from NDC accounts amounted to RMB 14 billion yuan in $1997^{26}$ and accumulated to RMB 740 billion yuan by the end of $2004 .^{27}$ These figures prove that the financial stresses were only temporarily alleviated by postponing the due date of the huge IPD. The unsecured financial sustainability severely eroded public faith in the system. A total of 731 non-SOEs in Henan Province were interviewed in 2004 and 56 percent of them expressed their concern that the social insurance might not meet its promises in the future. ${ }^{28}$

\section{Portability and the integration level of risk pool}

Uneven access to social pension benefits based on the type of employment affects not only social justice but also the portability of those benefits. One might suffer a loss in pension benefits and contributions when moving from the state sector to the private sector. Additionally, the fragmentation of the social pillar also inhibits labor flow among different regions by making it costly.

It is an established tradition in China's old-age insurance system that the responsible government agency (MOLSS) develops general templates of pension schemes, and the risk pools fill in the details and enact measures compatible with local conditions. For

${ }^{25}$ When China decided to launch the nationwide pension reform in 1997, confronting the challenging problem of how to deal with those who had already retired or were then employed became inevitable. These people's contributions to the former PAYG system had been used up to support retirees and there were no funds accumulated for them. To ensure a smooth transition, the government decided to adopt a set of differentiated benefit formulas. Those who had retired before the "new deal" could still get the pension benefits defined in the old system, and those who were already employed before the "new deal" but not retired would get the primary pension and individual account pension plus a so-called "transitional pension" in order to make sure their pension benefits would not be lower than that of the old system.

${ }^{26}$ See Sun (2001).

${ }^{27}$ See Liu (2005).

${ }^{28}$ Henan Statistics Bureau. 
example, different risk pools could define their own contribution ratios and administration fees. This principle has contributed to differentiation between risk pools and compromised the portability of social pension benefits. As market-oriented reforms progress, it is not unusual for a worker to have different employers through his/her working life. The issue of the transfer of pension benefits and the portability of pensions has become increasingly important.

According to the Notice to Establish Provincial Pools of Basic Old-Age Insurance issued in 1998, all those county-, city-, or industry-level pension pools should have been integrated at the provincial level by the end of 2000. This goal, however, has so far not been attained. The reasons behind this are complex. First, the former social pension system had firmly entrenched itself by building up a set of bureaucratic systems and corresponding personnel systems with consistent patterns of recruitment and stable linear careers; the establishment of provincial-level pension pools is expected to be accomplished by the insiders, that is, those who have vested interests in the old system. The measures to reform the reformers themselves were without doubt resisted. Second, adverse selection arose in the process of risk pools expansion. Due to prevalent regional disparities in economic and social development, county and city pools with lower dependent ratios and surpluses in PAYG accounts were reluctant to transfer control over the money to their superior administrations; contributors in counties and cities with a higher average wage level resisted the integration at the provincial level. As a result, fragmentation is still a pending issue in China's urban oldage insurance system and the integration of risk pools is unlikely to be achieved in the short term.

\section{Fund administration and management}

At present, social pension reserve funds (and, in some cases, employer pension funds) are basically under the control of local Labor and Social Security Bureaus, which are components of local governments (counties, cities, prefectures, and provinces). Contributions are expected to be deposited into separately managed banking accounts and can only be invested in the form of banking saving accounts, government bonds, and other investments as approved by the State Council. The most important role of high-level pension pools is to act like a reinsurer, that is, redistributing surplus from a subset of local accounts to deficit accounts. It is selfevident that the first priority of funds management is put on safety. In view of the empty individual accounts, returns on social old-age insurance funds are of less concern at present.

The dispersed funds administration system, however, makes it very difficult to ensure safe and sound management of pension reserve funds. The problem deserves special emphasis due to the absence of a complete and effective regulation system of social pension funds management in China. A recent corruption scandal involving pension funds in Shanghai highlighted this absence. The affair began in early August 2006, when the director of the Shanghai Labor and Social Security Bureau, which supervises the city's pension funds, was accused of lending RMB 3.2 billion yuan from pension funds to a private toll road company. Other illegal uses of social security funds 
for real estate speculation and other business ventures were also exposed. This scandal caused severe damage to the public trust in government.

On the other hand, the good faith of the general public and enterprises is also doubtful. Old-age insurance fraud is a good example. According to a nationwide investigation of 36 million beneficiaries by MOLSS agencies in 2005, about 62,000 had filed false claims, which cost the system RMB 160 million yuan. Besides, it is not unusual for enterprises to want to make a false report of their payroll to lower their contribution liabilities. In 2005, a regular audit found that the reported number of employees for whom enterprises are obligated to make contributions to the social insurance pools was 10 million less than the true value (MOLSS). Given the fact that China's labor supervision system is far from developed, as mentioned earlier, we can reasonably presume that the actual situation might be even worse.

\section{Summary}

To sum up, pension reform in China is still incomplete and many important issues remain. As many might argue that the direction in which China is steering pension reforms is the right one, we have to concede that the pace and sequencing of implementation are problematic and efforts and time are needed to attain the goal. Since the targeted pension system is based on the rationale that responsibilities of providing the old-age security should and must be shared to cope with the inevitable ageing trend, we will argue that the private sector, including the insurance industry of course, should participate actively in China's pension system. The evolving demographic mix and imperfect social pension system will undoubtedly bring valuable opportunities to China's insurance industry.

\section{Opportunities for insurance}

As we have seen, development of the third, voluntary individual pension pillar is already taking off as evidenced by the rapid growth of China's life insurance business. The current urban social old-age insurance focuses on providing the most basic economic security to retirees with a targeted income replacement ratio of 58.5 percent, which is often not attained in the real world. The actual replacement ratios in many risk pools are often less than 50 percent. For example, in 2003, the average replacement ratio attained in Beijing, Shanghai, and Guangzhou was 44.2, 41.1, and 37.8 percent, respectively. ${ }^{29}$ What's more, the coverage of the second pillar is quite limited. There does exist a high need for individual retirement plans, which is very likely to convert to real-world commercial insurance purchases combined with the increasing trends in personal financial assets and disposable income. In the past decade, the per capita annual disposable income of urban households has doubled and the corresponding Engle coefficient dropped from 48.8 percent in 1996 to 36.7 percent in 2005. As for the rural households, per capita annual disposable income increased

\footnotetext{
${ }^{29}$ Beijing, Shanghai, and Guangzhou Bureau of Ministry of Labor and Social Security.
} 
70 percent in the same period with an 11 percentage decrease of the Engle coefficient to 45.5 percent. $^{30}$ As a unique tool to manage longevity risk, pension insurance would embrace solid growth in the ageing society.

The second pillar, employer pension plans, is also promising to life insurance companies. In the accumulation period of employer pension plans, life insurance companies can get involved with this pillar after being accredited to act as fiduciary, trustee, and/or record keeper. Specialized insurance asset management companies ${ }^{31}$ and pension insurers might also qualify as investment custodians. Insurance companies, however, are not necessarily the preferred service provider in the competition with banks, securities firms, and trust facilities. For example, commercial banks are usually the most favorable trustees because of their advantages in clearing and settlement. Insurance companies might get superior status in the competition for the role of record keeper. In addition, insurance companies could play an important role in the liquidation period of employer pension plans given their actuarial skills, experience in production of various annuities, and service network.

Although the private sector has not been involved in the first pillar of China's pension system up to now, there is no material evidence that public-private sector partnership cannot help in efficient and expeditious implementation of social insurance policies. NCSSF is now employing a number of specialized pension fund investment companies, which are operating in a competitive environment under the general supervision of the NCSSF, indicating that the active participation of private pension fund investment is expected to lead to improved investment results. We would argue that insurance companies can contribute their administrative and management skills in account management and actuarial services to the first pillar, provided they meet the high standards of professional competence and integrity. If the government decided to find a right balance between public administration and private sector support, we might see opportunities for the insurance industry in the first pillar.

\section{Conclusion}

China has made a good start in laying the foundation for a multi-pillar pension system. The financing burden is being shared by employees, employers, and the government rather than being borne exclusively by the individual enterprises. A partially funded social pension system and supplementary employer pension plans are set to provide more stable old-age security than the former PAYG system.

Pension reform, however, is still incomplete and many important issues remain. Further expansion of social old-age insurance coverage and integration of social pension pools are pressing issues. The empty individual accounts need to be filled and

\footnotetext{
${ }^{30}$ National Bureau of Statistics of China (2006).

${ }^{31}$ Insurance asset management companies specializing in fund management for insurance companies have become the latest trend in insurance investment in China. PICC Asset Management Company and China Life Asset Management Company, established in 2003 and 2004, respectively, were the first two asset management companies in China.
} 
funds need to be raised to cover the huge IPD. Contributors and beneficiaries must be assured that accurate records are being kept and that funds are properly managed. China also needs to establish a sound and efficient safeguard system to secure pension funds, while putting more emphasis on funds investment than before. Pension reform in China is not only very urgent, but also extraordinarily complex, both administratively and policywise.

Meanwhile, we should always be aware of the fact that the social insurance system alone cannot realistically accomplish the task of providing old-age security in an ageing society with a continent-size population. The targeted multi-pillar pension system is based on this very fact. Responsibilities should be shared among the government, employers, and individuals. The private sector should be mobilized to play an active role in the pension system. Consequently, there exist many opportunities for the insurance industry.

\section{References and further reading}

China Center for Insurance and Social Security Research (Peking University) (2004) 'On the establishment of personal economic security system', China's Securities Journal, June 2, p. 19.

Gao, S. (2004) 'Social security in China: Which path should we choose?', China Securities Journal, January 9: p. 9, and January 13: p. 18.

Liu, Y. (2005) Keynote Speech at Beida CCISSR Forum 2005, April 20, Beijing, China: Peking University. Ministry of Labor and Social Security (2007) 2006 Communique on China's Labor and Social Security, Beijing, China: Ministry of Labor and Social Security.

National Bureau of Statistics of China (2006) China Statistical Yearbook 2006, Beijing: China Statistics Press; Beijing Info Press.

National Council for Social Security Fund (2006) 2005 Annual Report of National Social Security Fund, June 21, Beijing: National Council for Social Security Fund.

News Office of the State Council (2006) The Development of China's Undertakings for the Aged, Beijing: News Office of the State Council.

Principal Life Insurance Company (2004) The Principal Global Financial Well-Being Study: 2004 Executive Summary, Des Moines, IA, USA: Principal Life Insurance Company.

Song, X. (2001) Reforms of China's Social Security System, Beijing: Tsinghua University Press.

Sun, Q. (2001) 'Empty individual accounts and transition costs: On the effects of China's pension system reform', Economic Research Journal 5: 48-56.

Sun, Q., Suo, L. and Zheng, W. (2007) 'China's insurance industry: Developments and prospects', in J.D. Cummins and B. Venard (eds) Handbook of International Insurance: Between Global Dynamics and Local Contingencies, New York: Springer, pp. 595-637.

Sun, Q. and Zheng, W. et al. (2005) Studies on China's Social Security System: Reforms of Social Insurance System and Development of Commercial Insurance, Beijing: China Financial Publishing House.

United Nations Department of Economic and Social Affairs Population Division (2007) Major Developments and Trends in Population Ageing, February 7-9, New York: United Nations.

\section{About the Authors}

Qixiang Sun holds the Aviva Chair of Risk Management and Insurance, and is Associate Dean of International Affairs at School of Economics, Peking University, China. She is also the Chair of the Department of Risk Management and Insurance in the School and the Director of China Centre for Insurance and Social Security Research. She is widely recognized as one of China's leading insurance scholars. Her academic work in insurance has been published in China's top insurance and 
economics journals, as well as international insurance journals. Her textbook Insurance is the top-selling insurance textbook in China.

Lingyan Suo is now a post-doctoral research fellow at School of Public Health, Boston University, U.S.A. Her recent research has focused on the development strategy of China's insurance industry and reform of China's Social Security system. She received her doctoral degree of Economics from Peking University, China, in 2007. 